\title{
Resolution of electrocardiographic signs of myocardial infarction after potassium, glucose and insulin therapy
}

\author{
B. MitTrA* \\ M.B., Ph.D., M.R.C.P.E., D.T.M. \& H. \\ Department of Medicine, The Queen's University, Belfast 12
}

DeCREASE in intracellular potassium concentration with simultaneous increase in the concentrations of sodium, chloride and water as a result of myocardial ischaemia (Dennis \& Moore, 1938; Jennings et al., 1957 ; Russell et al., 1961 ; Prioreschi, 1963) is believed to be responsible for electrocardiographic (ECG) alterations in cardiac infarction (Gubner \& Behr, 1957; Cummings, 1960 ; Prinzmetal et al., 1961, 1962). Hypopolarization of the myocardial cell, caused by these electrolytic alterations, results in reduction of its resistance so that the cell is more liable to act as an irritable focus. Cardiac arrhythmias, generated in this way, account for the majority of deaths in acute myocardial infarction (Julian et al., 1964 ; Goble et al., 1966).

Sodi-Pallares et al. (1962a) observed restitution of intracellular potassium concentration, diminution in injury current as recorded on the ECG, and diminished excitability of the myocardium following the use of potassium, glucose and insulin (PGI) therapy in experimental cardiac infarcts. This regimen has already been shown to be capable of causing significant reduction in mortality in patients with myocardial infarction (Mittra, 1965), mainly by preventing deaths due to arrhythmias (Mittra, 1967).

The close relationship between improvement in biochemical abnormality at the myocardial cellular level and the resolution of ECG changes of infarction provided an opportunity to test the efficacy of PGI therapy in clinical subjects with myocardial infarction and ischaemia by measuring the improvement on the ECG and comparing it with the progress of other patients acting as controls.

\section{Material and methods}

The subjects of the present study belonged to the treated and coritrol groups of a clinical trial which was designed to test the efficacy of PGI therapy in myocardial infarction. The criteria for diagnosis of infarction, details of the regimen and the results obtained in the trial have been

\footnotetext{
*Present appointment: Consultant Physician, The General Hospital, Sunderland, Co. Durham.
}

published elsewhere (Mittra, 1965). All the patients received anticoagulant therapy. Other medication was avoided as far as possible but drugs such as digitalis, quinidine, diuretics and vasopressors were given when necessary; administration of these drugs was independent of whether patients were in the control or treated groups.

All patients included in the trial had a standard twelve-lead ECG recorded on admission. This was repeated at least once every 3rd day, and more frequently if necessary, throughout their stay in hospital which varied from 3 to 6 weeks. ECG tracings of patients, who were connected to the monitor, were continuously recorded on a magnetic tape from which single lead ECG recordings could be obtained. Further ECG recordings were taken at the follow-up examination of these patients some 3-4 weeks after discharge from hospital.

Comparisons were made between the two groups with regard to the distribution of patients according to electrical location of the infarct; the influence of the location of the infarct and of the regimen on the mortality was also assessed.

Of the eighty-five patients in either group of the trial, four treated patients and nineteen controls died within $48 \mathrm{hr}$ of admission. Also, two patients, one from each group, had left bundlebranch block on admission. The changes of resolution could not have been detected on their ECGs and hence they were excluded from this part of the analysis. Distribution of the remaining patients, eighty treated and sixty-five controls, according to the patterns noted on the ECG was then compared in order to establish similarity between the two groups. The serial ECGs recorded in these patients were analysed as follows: Complexes with the best isoelectric lines were chosen and measurements of the abnormalities were made in the leads with maximum voltage. The grades of injury were determined by the positive displacement of the $S-T$ segment, and the grades of ischaemia by the negative voltage of the $S-T$ segment and/or the $T$ waves, scale used being $0.1 \mathrm{mV}=1$ unit. The magnitude of the change (difference between maximum and minimum unit 
values) was then plotted against time in days in each case as a scatter diagram. Regression of the former on the latter was calculated in patients of both groups and the result was then statistically tested to detect differences.

\section{Results}

The distribution of patients according to the electrical location of the infarct was similar in the treated and control groups of the trial (Tables 1 and 2). Although mortality was slightly higher

TABLE 1

Electrical location of infarct and associated mortality

(Comparison between control and treated groups of the clinical trial)

\begin{tabular}{|c|c|c|c|c|c|c|c|c|}
\hline \multirow[b]{2}{*}{ Location } & \multicolumn{4}{|c|}{ Control } & \multicolumn{4}{|c|}{ Treated } \\
\hline & $\begin{array}{l}\text { No. of } \\
\text { patients }\end{array}$ & $\begin{array}{c}\text { Incidence } \\
(\%)\end{array}$ & $\begin{array}{l}\text { Deaths } \\
\text { (No.) }\end{array}$ & $\begin{array}{c}\text { Mortality } \\
(\%)\end{array}$ & $\begin{array}{c}\text { No. of } \\
\text { patients }\end{array}$ & $\begin{array}{c}\text { Incidence } \\
(\%)\end{array}$ & $\begin{array}{l}\text { Deaths } \\
\text { (No.) }\end{array}$ & $\begin{array}{c}\text { Mortality } \\
(\%)\end{array}$ \\
\hline A. Anterior infarct (Total) & 44 & $51 \cdot 8$ & 18 & 41 & 38 & $44 \cdot 7$ & 8 & 21 \\
\hline (i) Anterior & 24 & $28 \cdot 2$ & 8 & $33 \cdot 3$ & 21 & $24 \cdot 7$ & 5 & 24 \\
\hline (ii) Antero-septal & 11 & 13 & 7 & $63 \cdot 6$ & 9 & $10 \cdot 6$ & 2 & $22 \cdot 2$ \\
\hline (iii) Antero-lateral & 8 & $9 \cdot 4$ & 2 & 25 & 7 & $8 \cdot 3$ & 1 & $14 \cdot \overline{3}$ \\
\hline (iv) High anterior & 1 & $1 \cdot 2$ & 1 & 100 & 1 & $1 \cdot 2$ & 0 & 0 \\
\hline B. Posterior infarct (Total) & 35 & $41 \cdot 2$ & 11 & $31 \cdot 4$ & 39 & $45 \cdot 9$ & 4 & $10 \cdot 3$ \\
\hline (i) Posterior & 17 & 20 & 6 & $35 \cdot 3$ & 20 & $23 \cdot 5$ & 3 & 15 \\
\hline (ii) Postero-septal & 11 & 13 & 4 & $36 \cdot 4$ & 3 & $3 \cdot 5$ & 1 & $33 \cdot 3$ \\
\hline (iii) Postero-lateral & 7 & $8 \cdot 2$ & 1 & $14 \cdot 3$ & 16 & 19 & 0 & 0 \\
\hline C. Combined (anterior + & & & & & & & & \\
\hline $\begin{array}{ll} & \text { posterior) } \\
\text { D. } & \text { Unknown (left bundle- }\end{array}$ & 5 & $5 \cdot 9$ & 1 & 20 & 7 & $8 \cdot 2$ & 2 & 28 \\
\hline branch block) & 1 & $1 \cdot 2$ & 0 & 0 & 1 & $1 \cdot 2$ & 0 & 0 \\
\hline Total No. of patients & 85 & 100 & 30 & $35 \cdot 3$ & 85 & 100 & 14 & $16 \cdot 5$ \\
\hline
\end{tabular}

TABLE 2

Statistical analysis

\begin{tabular}{|c|c|c|c|c|c|c|c|c|c|}
\hline \multicolumn{6}{|c|}{ Control vs. treated according to location of infarct } & \multicolumn{4}{|c|}{$\begin{array}{l}\text { Mortality } \\
\text { anterior } v s . \text { posterior infarct }\end{array}$} \\
\hline \multirow{2}{*}{\multicolumn{2}{|c|}{ Distribution }} & \multirow{2}{*}{\multicolumn{4}{|c|}{$\frac{\text { Mortality }}{\text { Anterior infarct Posterior infarct }}$}} & \multirow{2}{*}{\multicolumn{2}{|c|}{ Control }} & \multirow{2}{*}{\multicolumn{2}{|c|}{ Treated }} \\
\hline & & \multicolumn{2}{|c|}{ Anterior infarct } & Posterior infarct & & & & & \\
\hline $\begin{array}{r}2 \\
2 \\
\end{array}$ & $P$ & $\begin{array}{r}2 \\
x_{1}^{2} \\
\end{array}$ & $P$ & $\begin{array}{r}2 \\
x_{1}^{2} \\
\end{array}$ & $P$ & $\begin{array}{r}2 \\
x_{1}^{2} \\
\end{array}$ & $P$ & $\begin{array}{r}2 \\
x_{1}\end{array}$ & $P$ \\
\hline 0.66 & $>0.7$ & 3.624 & $>0.05$ & $5 \cdot 128$ & $<0.05^{*}$ & 0.755 & $>0.3$ & $1 \cdot 67$ & $>0.1$ \\
\hline
\end{tabular}

TABLE 3

Classification of patients in the treated and control groups of the trial according to ECG changes

\begin{tabular}{|c|c|c|c|c|}
\hline \multirow{3}{*}{ Types of ECG abnormality } & \multicolumn{4}{|c|}{ Groups } \\
\hline & \multicolumn{2}{|c|}{ Control } & \multicolumn{2}{|c|}{ Treated } \\
\hline & No. I & Incidence $(\%)$ & No. & Incidence $(\%)$ \\
\hline $\begin{array}{l}\text { A. Depression of } S-T \text { segment and/or } \\
T \text { wave inversion only }\end{array}$ & $12(3)$ & $14 \cdot 1$ & 6 & 7 \\
\hline B. Elevation of $S-T$ segment only & $9(1)$ & $10 \cdot 6$ & $10(1)$ & $11 \cdot 8$ \\
\hline $\begin{array}{c}\text { C. Pathological } Q \text { waves with elevation } \\
\text { or depression of } S-T \text { segment }\end{array}$ & $52(7)$ & $61 \cdot 1$ & $67(3)$ & $78 \cdot 8$ \\
\hline $\begin{array}{l}\text { D. Right bundle-branch block. No change } \\
\text { in } S-T \text { segment }\end{array}$ & $2(2)$ & $2 \cdot 4$ & 0 & \\
\hline $\begin{array}{l}\text { E. Right bundle-branch block with } \\
\text { elevation of } S-T \text { segment }\end{array}$ & $9(6)$ & $10 \cdot 6$ & 1 & $1 \cdot 2$ \\
\hline F. Left bundle-branch block & 1 & $1 \cdot 2$ & 1 & $1 \cdot 2$ \\
\hline Total no. of patients & $85(19)$ & & $85(4)$ & \\
\hline
\end{tabular}

Figures given in parentheses denote the number of patients who died within $48 \mathrm{hr}$ of admission. The data from them were excluded from the analysis of the effect of PGI therapy on the resolution of ECG signs of myocardial infarction and ischaemia. 
in patients with anterior infarct than with posterior damage in both groups, the differences were statistically not significant (Tables 1 and 2).

Considerable reduction in mortality was observed among treated patients with anterior and posterior infarcts when compared with the controls. The differences reached statistical significance $(P<0.05)$ for the group with posterior damage but not for those with anterior infarcts $(P>0.05)$. The number of patients with combined infarcts and left bundle-branch block was so small that statistical analysis was not possible (Tables 1 and 2).

Right bundle-branch block and ischaemic changes such as depression of $S-T$ segment with or without $T$ wave inversion were more frequently observed among controls when compared with the treated group (Table 2). Pathological $Q$ waves were noted in fifty-two controls $(61 \%)$ and sixtyseven $(79 \%)$ of treated patients. Exclusion of patients who died within $48 \mathrm{hr}$ of admission made the ECG patterns observed among the treated and control patients comparable so that the differences between the two could be analysed (Table 3 ).

Treated patients achieved a similar degree of ECG improvement $(P>0.6)$ in a significantly $(P<0.01)$ shorter period of time when compared with the controls (Fig. 1). Fig. 2 depicts the speed with which some treated patients achieved resolution of the signs of injury. On the whole, this improvement was noted to be quicker after intravenous rather than oral and subcutaneous administration of the regimen.

\section{Discussion}

The distribution of patients according to the electrical location of infarcts in the present study is similar to that observed in other series (Julian et al., 1964 ; Klausner et al., 1964).
The regimen proved to be more beneficial to patients with posterior rather than anterior infarcts probably because serious arrhythmias such as heart block and nodal rhythm are more frequently associated with posterior damage (Gilchrist, 1958 ; Courter et al., 1963 ; Julian et al., 1964) and the efficacy of the regimen in preventing deaths due to these disturbances has already been demonstrated (Mittra, 1966).

It is generally agreed that hypopolarization of the damaged cells in myocardial infarction (caused by loss of intracellular potassium) is responsible for elevation of $S-T$ segment from the isoelectric line (Samson \& Scher, 1960; Prinzmetal et al., 1959, 1961, 1962 ; Salmanovich, 1966). However, there are minor points of disagreement between various workers regarding the detailed interpretation of this basic hypothesis. Samson \& Scher (1960) believe that the hypopolarization occurs in systole, whereas Prinzmetal et al. (1959, 1961, 1962) have shown that the electrical changes are mainly confined to diastole. Salmanovich (1966) is in agreement with the latter view but maintains that diastolic hypopolarization due to loss of intracellular potassium is only responsible for the initiation of $S-T$ segment elevation. According to him, this elevation is subsequently maintained by the creation of a hypopolarized zone around the necrotic area due to the entry of potassium, which had earlier leaked out of the damaged cells, into the adjacent healthy regions of the myocardium (Herles \& Daum, 1957).

Significantly $(P<0.01)$ speedier resolution of the ECG signs of myocardial infarction and ischaemia was observed in the treated patients when compared with the controls. This is in accord with the experience of others (SodiPallares et al., 1962b, 1963, 1966; Fritz, 1965 ;

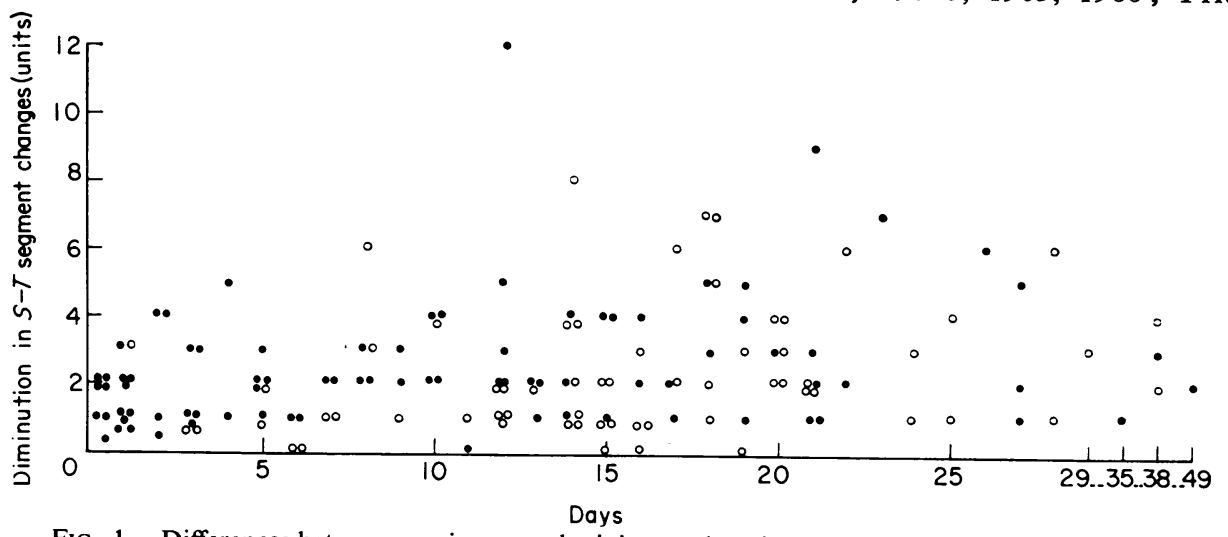

Fig. 1. Differences between maximum and minimum elevation (or depression) of $S-T$ segment or inversion of $T$ wave (measured in units) plotted against time (in days) taken to achieve such a degree of improvement. Resolution of ECG signs of infarction and ischaemia was noted to be significantly $(P<0.01)$ speedier in the treated group $(\Theta)$ when compared with the controls $(O)$. 


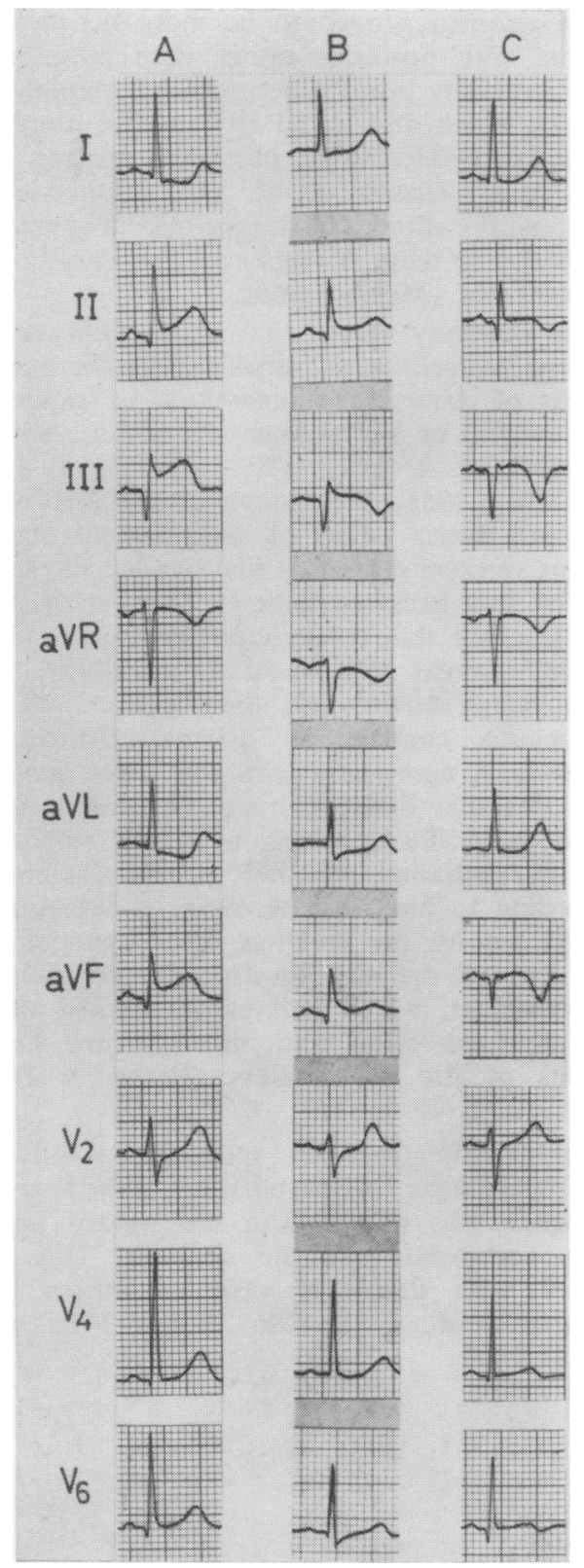

Fig. 2. (A) 10 August 1964-ECG changes of posterior myocardial infarction on admission. Intra venous (i.v.) administration of potassium, glucose and insulin (PGI) therapy was commenced $4 \mathrm{hr}$ after admission. (B) Considerable resolution of the ECG signs of infarction $1 \mathrm{hr}$ after onset of therapy. (C) 25 August 1964-Steady improvement was maintained. ECG shows further resolution.

Larcan, 1966). Prinzmetal et al. (1959, 1961, 1962) have conclusively shown that the restitution of the intracellular potassium concentration in the damaged myocardial cells is associated with the diminution of $S-T$ segment elevation, and hyperpolarization of the same cells (as a result of overcorrection of intracellular potassium deficit) results in depression of the $S-T$ segment from the isoelectric line. Therefore, the electrocardiographic improvement observed following the use of PGI therapy in patients with myocardial infarction and ischaemia should not be dismissed as just an isolated electrolytic effect, but should be taken as proof that the use of the regimen results in the restoration of intracellular membrane potential of the hypopolarized cells. If Salmanovich's (1966) hypothesis for $S-T$ segment elevation is correct, then the ECG improvement should also be taken to indicate that the regimen can disperse the increased extracellular potassium aggregation in the perinecrotic area probably by driving it into the damaged myocardial cells.

\section{Summary}

Significantly $(P<0.01)$ quicker resolution of the ECG signs of myocardial infarction and ischaemia was observed among patients treated with potassium, glucose and insulin therapy when compared with a similar control group. Available evidence suggests that the electrocardiographic improvement caused by the regimen can be correlated with the restoration of the intracellular potassium concentration (and hence the resting membrane potential) of the damaged myocardial cells and the removal of excess potassium from the extracellular spaces of the perinecrotic zone. The results of the present study, therefore, provide evidence for the corrective influences of the regimen on the biochemical and electrophysiological abnormalities which occur at the cellular level in myocardial infarction.

For reference to the earlier work of Laborit see discussion by Carlo (Postgrad. med. J., 1967, 43, 217)-Editor.

\section{References}

Calva, E., Mujica, A., Bisteni, A. \& Sodi-Pallares, D. (1965) Oxidative phosphorylation in cardiac infarct. Effect of glucose-KCl-insulin solution. Amer. J. Physiol. 209, 371.

Courter, S.R., Moffat, J. \& Fowler, N.O. (1963) Advanced atrioventricular block in acute myocardial infarction. Circulation, 27, 1034.

Cummings, J.R. (1960) Electrolyte changes in heart tissue and coronary arterial and venous plasma following coronary occlusion. Circulat. Res. 8, 865.

DenNis, J. \& Moore, R.M. (1938) Potassium changes in functioning heart under conditions of isehemia and of congestion. Amer. J. Physiol. 123, 443.

FrITZ, E. (1965) Untersuchungen zur Behandlung des Myokardinfarktes mit Insulin-Glukose-Infusionen. $Z$. Kreisl.-Forsch, 54, 274.

Gilchrist, A.R. (1958) Clinical aspects of high-grade heart block. Scot. med.J. 3, 53.

Goble, A.J., Sloman, G. \& Robinson, J.S. (1966) Mortality reduction in a coronary care unit. Brit. med. J. i, 1005. 
Gubner, R.S. \& Behr, D.J. (1957) Role of electrolytes in origin of ischaemic cardiac pain and associated electrocardiographic abnormalities. Circulation, 16, 889.

Herles, F. \& Daum, C. (1957) Potassium migration in myocardial infarction and the electrocardiogram. Therap. Arch. 29, 20 (in Russian) as quoted by Salmanovich, V.S. Electrolytes and Cardiovascular Diseases (Ed. by $\mathrm{E}$. Bajusz), Vol. 2, p. 102. Karger, Basel, 1966.

Jennings, R.B., Crout, J.R. \& Smetters, G.W. (1957) Studies on distribution and localization of potassium in early myocardial ischaemic injury. AMA Arch. Path. 63, 586.

Julian, D.G., Valentine, P.A. \& Miller, G.G. (1964) Disturbances of rate, rhythm and conduction in acute myocardial infarction. Amer. J. Med. 37, 915.

Klausner, M., Simon, F. \& Bernstein, A. (1964) Arrhythmias associated with acute mypcardial infarction. $J$. Newark Beth Israel Hosp. 15, 135.

Larcan, A. (1966) Pathophysiological basis and practical application of a 'metabolic' therapy of myocardial infarction. Electrolytes and Cardiovascular Diseases (Ed. by E. Basujz), Vol. 2, p. 277. Karger, Basel.

Mittra, B. (1965) Potassium, glucose and insulin in treatment of myocardial infarction. Lancet, ii, 607.

Mittra, B. (1966) Potassium, glucose and insulin in treatment of heart block after myocardial infarction. Lancet, ii, 1438.

Mirtra, B. (1967) Potassium, glucose and insulin in treatment of myocardial infarction. Brit. Heart J. 29, 616.

Prinzmetal, M., EKmekcI, A., TOYOShima, H. \& KwoczYnski, J.K. (1959) Angina pectoris. III. Demonstration of a chemical origin of S-T elevation in classic angina pectoris, its variant form, early myocardial infarction, and some noncardiac conditions. Amer. J. Cardiol. 3, 276.

Prinzmetal, M., Toyoshima, H., Ekmekci, A., Mizuno, Y. \& NAGAYA, T. (1961) Myocardial ischaemia. Nature of ischaemic electrocardiographic patterns in the mammalian ventricles as determined by intracellular electrographic and metabolic changes. Amer. J. Cardiol. 8, 493.
Prinzmetal, M., Toyoshima, H., Ekmekci, A. \& Nagaya, T. (1962) Angina pectoris. IV. The nature of $S$ - $T$ segment elevation and other ECG change in acute severe myocardial ischaemia. Clin. Sci. 23, 489.

PrioresChI, P. (1963) Chlorides, potassium and experimental cardiac necroses. Circulat. Res. 12, 55.

Russell, R.A., Crafoord, J. \& Harris, A.S. (1961) Changes in myocardial composition after coronary artery ligation. Amer. J. Physiol. 200, 995.

Salmanovich, V.S. (1966) Ionic nature of the shift of the $S-T$ segment in myocardial ischaemia and infarction. Electrolytes and Cardiovascular Diseases (Ed. by $\mathrm{E}$. Bajusz), Vol. 2, p. 100. Karger, Basel.

Samson, W.E. \& Scher, A.M. (1960) Mechanism of $S-T$ segment alteration during acute myocardial injury. Circulat. Res. 8, 780.

Sodi-Pallares, D., Bisteni, A., Medrano, G.A., de Micheli, A., Ferrer, G., Contreras, R. \& ZetinaMORA, E. (1962a) Effects of the polarizing solution, glucose-insulin-potassium on the electrocardiogram, electrolytes and morphology of acute experimental myocardial infarction. Int. Congr. Cardiol., Mexico, Vol. IV-b, p. 226.

Sodi-Pallares, D., Testrlli, M.R.. Fishleder, B.L., Bisteni, A.. Medrano, G.A., Friedland, C. \& DE Micheli, A. (1962b) Effects of an intravenous infusion of a potassium-glucose-insulin solution on the electrocardiographic signs of myocardial infarction. A preliminary clinical report. Amer. J. Cardiol. 9, 166.

Sodi-Pallares, D., Bisteni, A., Medrano, G.A., Testelli, M.R. \& DE Micheli, A. (1963) The polarizing treatment of acute myocardial infarction. Possibility of its use in other cardiovascular conditions. Dis. Chest, 43, 424.

Sodi-Pallares, D., Bisteni, A., Medrano, G.A., De Micheli, A., Ponce de Leon, J., Calva, A., Fishleder, B.L., Testelli, M.R. \& Miller, B.L. (1966) The polarizing treatment in cardiovascular conditions, experimental basis and clinical applications. Electrolytes and Cardiovascular Diseases (Ed. by E. Bajusz). Vol. 2, p. 198. Karger, Basel. 